\title{
POWER STAKEHOLDER DALAM BISNIS
}

\author{
Ali Hasan \\ NIDN 0007106001 \\ email: Ali43ibc@gmail.com \\ Dosen Sekolah Tinggi Pariwisata AMPTA Yogyakarta
}

\begin{abstract}
The purpose of the literature review is to explain that stakeholder theories have the right role in the production of business and stakeholder values, the enhancement of stakeholder voices and the advocacy of stakeholders. The focus is on normative theory, the dimensions of stakeholder theory and business performance. Discussion of stakeholder theory is done descriptively in relation to power, legitimacy and their urgency related to stakeholder type in influencing company performance especially in maximizing value and financial performance of company. The stakeholder concept has gained legitimacy among academics in various fields. stakeholder theory will provide benefits in relationships if understanding and integration of stakeholder concepts in management perceptions that their existence has a positive power in build of corporate advantage.
\end{abstract}

Keywords : Stakeholder power, Business and Management

\section{PENDAHULUAN}

Teori stakeholder menghubungkan norma dengan strategi perusahaan. Perusahaan yang selalu mencari cara untuk melayani kepentingan stakeholder akan menciptakan nilai lebih dari waktu ke waktu. Power stakeholder sebagai instrumen bisnis yang penting dalam menciptakan kinerja yang bermakna bagi semua pihak yang terlibat dengan perusahaan. Legitimasi dan power selalu berkaitan dengan batasan kewajiban dan hak tertentu. Konsep nilai ekonomi yang relevan dibuat oleh perusahaan memberi peluang untuk mensejahtrakan para stakeholder, dan masing-masing ingin mendapatkan keuntungan dari waktu ke waktu melalui kerjasama dan keterlibatannya dalam perusahaan (Brand \& Gaffikin, 2007).

Teori stakeholder dianggap relevan oleh manajemen dalam hal power, legitimasi dan urgensi jika secara langsung mampu mempengaruhi strategi perusahaan dan keberlanjutan perusahaan, sebaliknya tidak bisa dianggap sebagai stakeholder. Dalam pengaruh tidak langsung didasarkan pada tingkat ketergantungan sumber daya perusahaan dan stakeholder atau posisi yang dipegang oleh perusahaan dalam jaringan stakeholder (Torfing, 2005). Kapasitas pengaruh stakeholder dapat dijelaskan dengan teori ketergantungan sumber daya yang menunjukkan bahwa perusahaan itu tidak bisa lepas dari pengaruh eksternal, mereka rentan terh

adap perubahan lingkungan yang mengendalikan sumber daya yang mereka butuhkan (misalnya tenaga kerja, bahan baku, teknologi, modal, dll).

Teori stakeholder kadang-kadang dianggap bertentangan dengan teori-teori perusahaan yang berakar pada teori ekonomi, terutama karana banyak yang percaya bahwa teori stakeholder pada dasarnya adalah 
normatif (sebagai teori yang berhubungan dengan etika dan moralitas bisnis), juga berperan sebagai teori yang berurusan dengan efektivitas bisnis. Teori stakeholder tidak hanya menyediakan kerangka kerja untuk bagaimana korporat harus melakukan bisnis tetapi juga menunjukkan bahwa beberapa stakeholder mengamankan resources berwujud dan tidak berwujud (termasuk pengetahuan dan reputasi) yang untuk menciptakan kekayaan perusahaan atau nilai bagi pemegang saham. Aspek normatif teori stakeholder merupakan cara untuk memahami bagaimana prinsip-prinsip etika dapat memicu sistem pertukaran individu dan keuntungan ekonomi dalam jangka panjang.

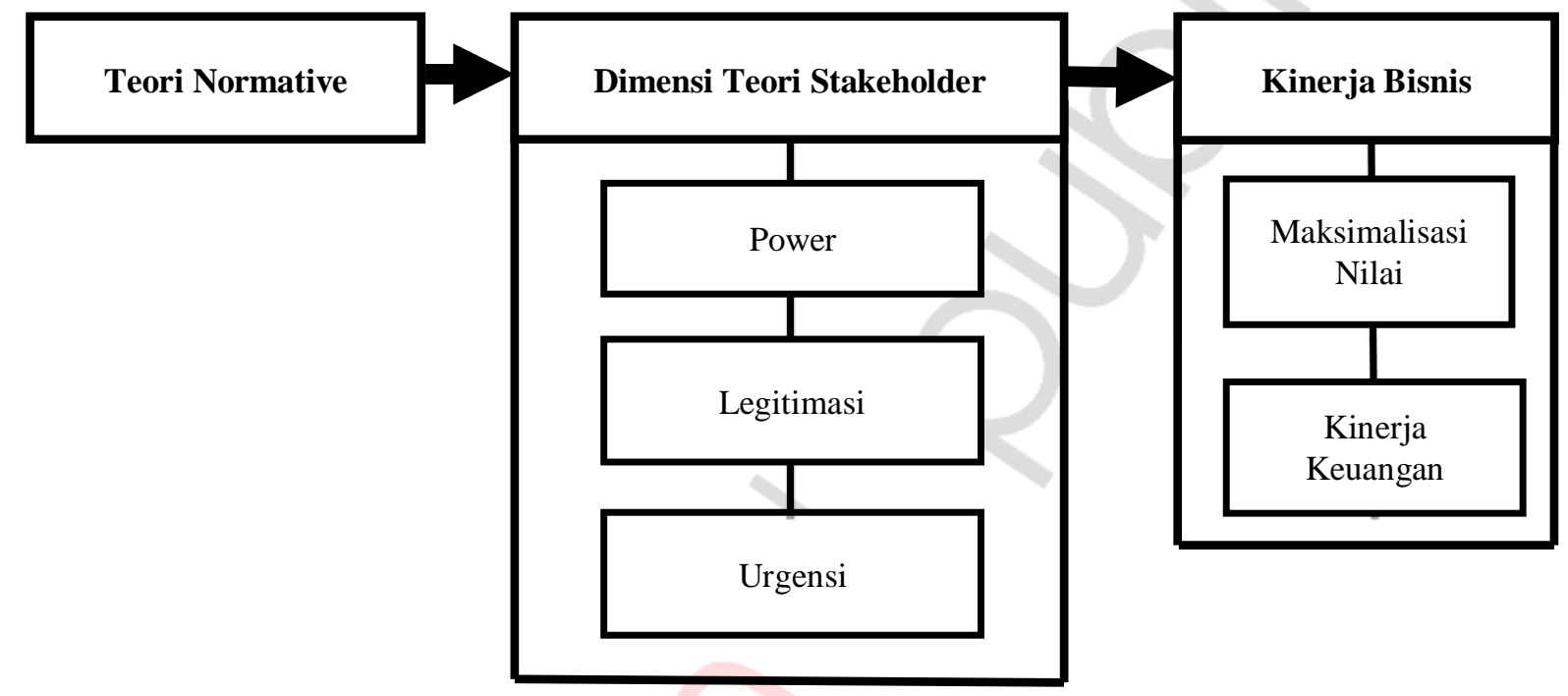

Gambar 1. Model Power Stakeholder dan Kinerja Bisnis

Stakeholder yang memiliki klaim hukum, dan moral dapat mempengaruhi perilaku, arah, proses, atau hasil perusahaan. Stakeholder memiliki kemampuan dan power untuk mempengaruhi perusahaan dengan cara dan legitimasi yang sah, komprehensif dan bermanfaat dalam membantu korporat menghindari masalah serta meningkatkan efektivitas perusahaan, meningkatkan kesejahteraan ekonomi, pengendalian kerusakan, mengoptimal-kan peluang, membangun power bersaing, membangun koalisi, dan karena itu manajer perlu memiliki cacatan lengkap semua stakeholder yang berpartisipasi dalam keseim-bangan kepentingan korporat.

\section{KONSEP DASAR}

Gambar 1 menunjukkan dinamisasi model stakeholder dimana teori normative sebagai basis pengembangan power, legitimasi dan urgensi stakeholder baik dalam aktivitas fungsional bisnis maupun kebijakan straregis untuk mempengaruhi kinerja bisnis seperti kinerja keuangan, kepuasan (stakeholder internal dan eksternal) dan keberlanjutan bisnis.

Orang, kelompok, korporasi, lembaga, dan masyarakat umumnya dianggap memenuhi syarat sebagai stakeholder aktual atau potensial. Perusahaan memiliki kewajiban terhadap kelompok konstituen dalam masyarakat selain pemegang saham dan di luar itu ditentukan oleh hukum atau kontrak. Stakeholder didefinisikan sebagai 
"individu atau sekelompok individu yang bertanggung jawab dalam mempengaruhi pencapaian tujuan perusahaan atau yang dipengaruhi oleh pencapaian tujuan perusahaan, mereka menjadi penentu apakah perusahaan untuk sebatas bertahan hidup atau maju secara berkelanjutan (Parmar, et al, 2010). Kontribusi besar teori ini akan terlihat jika korporat mampu menyeimbangkan perbedaan kepentingan stakeholder (Abell, 2009).

\section{Teori Normative Stakeholder Dalam Bisnis}

Kerangka pengembangan teori normatif menekankan pada pentingnya investasi dalam hubungan dengan orangorang yang memiliki saham di perusahaan dan stabilitas hubungan ini tergantung pada keseimbangan hubungan stakeholder dan manajemen (Diez, et al, 2015). Dengan teori stakeholder memungkinkan manajer untuk memasukkan nilai-nilai pribadi ke dalam perumusan dan implementasi rencana strategis, yang berkaitan dengan: Pertama, karakteristik ideal, legalitas hukum dan kelembagaan serta perilaku manajemen yang secara moral dapat diterima dalam konteks hukum dan kelembagaan bisnis yang ada. Kedua, diferensiasi kategori: bahwa stakeholder harus diperlakukan dengan cara yang bermartabat ketika membuat keputusan perusahaan; intermediasi yang dapat menggabungkan berbagai kepentingan dan permintaan stakeholder dalam perusahaan; partisipasi semua stakeholder dalam proses keputusan perusahaan. Perspektif ini menunjukkan bahwa para stakeholder layak dipertimbangkan, terlepas dari kemampuan mereka untuk menciptakan kekayaan bagi perusahaan. Ketiga, kebutuhan ter-hadap stakeholder, ketika perusahaan sedang "sakit", kewjiban dan tanggung jawab moral para stakeholder dibutuhkan oleh perusahaan dalam konteks yang berbeda sesuai dengan posisinya masing-masing, karena itu kewajiban keadilan perusahaan terhadap stakeholders dipandang sebagai unsur penting dari teori stakeholder normatif. Keempat, manajemen stakeholder diperlukan dalam rangka menangani klaim dan menyeimbangkan tuntutan yang berbeda, perusahaan harus memperlakukan kelompokkelompok stakeholder dengan adil, tidak hanya dalam hal ekonomi, tetapi juga mempertimbangkan aspek hubungan stakeholder dengan perusahaan sebagai bagian penting dari konsep manajemen strategis. Kelima, etika dan moralitas bisnis mempertimbangkan keseimbangan kepentingan stakeholder, dengan cara (a) stakeholder harus diperlakukan tidak hanya sebagai alat untuk mencapai tujuan; dan (b) mempertimbangkan bagaimana membuat keputusan, dan mendistribusikan hasil kepada stakeholder yang berbeda terkait dengan sifat dan tingkat tugas dalam mempengaruhi perusahaan. Keenam, konsep orientasi manajemen stakeholder, stakeholder yang sah harus diperhitungkan sebagai aksi strategis yang diinginkan oleh perusahaan dalam menangani kepentingan stakeholder yang memiliki nilai intrinsik yang dapat memenuhi keinginan stakeholder. Orientasi manajemen stakeholder normatif merupakan sikap manajerial terhadap stakeholder yang memiliki kepentingan asli dan sah, keadilan dan kebenaran satiap aspek yang terlibat dengan hubungan stakeholder dan manajemen.

\section{Dimensi Teori Stakeholder}

Konstruksi, definisi, asal-usul konsep dan dinamisasi teori stakeholder memiliki beberapa implikasi power, legitimasi, dan urgensi. Pertama, setiap dimensi dapat berubah - konstalasi hubungan stakeholder manajer dapat berubah setiap saat. Kedua, eksistensi masing-masing dimensi adalah masalah persepsi terhadap realitas sasaran 
bisnis yang dibangun. Ketiga, seorang individu atau kelompok mungkin tidak sadar dari dimensi teori yang dimiliki. Dimensi penting teori stakeholder menyediakan kerangka kerja untuk memahami bagaimana para stakeholder dapat memperoleh atau kehilangan urgensi dalam sebuah perusahaan.

Suatu entitas yang memiliki power dapat memaksakan kehendaknya pada sebuah perusahaan, namun power yang bagus adalah meletakkannya dalam konteks hubungan stakeholder dan manajer, penggunaan power stakeholder dipicu oleh kondisi yang terwujud dalam dua atribut lain: legitimasi dan urgensi. Artinya, power dengan sendirinya tidak menjamin hubungan stakeholder dengan manajer, otoritas power melalui legitimasi, dan eksistensi hubungan melalui urgensi.

Jaringan yang saling berhubungan dan bahkan di bawah kondisi tekanan tinggi sekalipun, manajer dan stakeholders dengan berbagai ketersediaan waktu, daya kognisi dan differensiasi stakeholder berdasarkan persepsi power, legitimasi, dan urgensi (Mitchell, et al 1997), dianggap ada jika manajer melihat stakeholder memiliki kemampuan untuk "memaksakan" kehendak mereka pada perusahaan.

\section{Power}

Power adalah fungsi dari akses kontrol berdasarkan penerapan sarana fisik, kontrol berdasarkan materi barang dan jasa, dan kontrol penggunaan simbol-simbol dalam suatu hubungan. Stakeholder memiliki legitimasi ketika manajer melihat tindakan mereka atau mengaku benar dan tepat, relatif terhadap standar yang berlaku di lingkungan kelembagaan di mana keduanya beroperasi. Akhirnya, para stakeholder memiliki urgensi ketika klaim mereka pada perusahaan dalam sensitifitas waktu yang penting (membahayakan) artinya bahwa urgensi stakeholder untuk manager tergantung pada kombinasi atribut stakeholder ini.

Power didefinisikan sebagai hubungan antar pelaku sosial dalam konteks kegiatan tertentu. Orang yang memegang power memiliki potensi untuk mempengaruhi perilaku, mengubah jalannya peristiwa, mengatasi perlawanan dan membujuk individu atau kelompok untuk bertindak dengan cara tertentu. Paling tidak ada tiga power potensial yang dimiliki oleh stakeholder: power voice, power politik dan power ekonomi.

a. Power voice, stakeholder juga seperti pemegang saham memiliki kemampuan untuk melaksanakan pengaruh langsung pada perusahaan melalui hak suara yang diberikan kepada mereka dengan diadakannya rapat pemegang saham perusahaan. Dengan demikian, hak suara memberikan pemegang saham kesempatan untuk mengekspresikan persetujuan mereka atau tidak tentang perubahan besar strategi perusahaan, khususnya, keputusan tentang pelaksanaan program bisnis.

b. Power politik, ini merupakan "kemampuan untuk mempengaruhi karena penggunaan proses politik". Power ini memungkinkan para stakeholder, melalui penggunaan mekanisme peraturan dan perundangundangan yang baru/yang ada, untuk mengontrol perilaku perusahaan yang terkait dengan kegiatan usaha.

c. Power ekonomi, ini berkaitan dengan "kemampuan untuk mempengaruhi karena keputusan pasar". Power ini merupakan jenis power yang paling signifikan tentang kemampuan stakeholder untuk mempengaruhi keputusan manajerial. Ketika kontrol stakeholder atas sumber daya 
meningkat, power ekonominya menjadi lebih kuat.

\section{Legitimasi}

Gagasan legitimasi, mengacu pada struktur atau perilaku sosial yang dapat diterima dan diharapkan, dan sering digabungkan secara implisit dengan power ketika orang mencoba untuk mengevaluasi sifat hubungan dalam perusahaan. Dalam jangka panjang, mereka yang tidak menggunakan power dengan cara yang dianggap bertanggung jawab akan cenderung kehilangan kesempatan.

Banyak akademisi menjelaskan bahwa legitimasi dan power adalah atribut yang berbeda yang dapat digabungkan untuk menciptakan otoritas (penggunaan power yang sah) tetapi juga bisa eksis secara independen. Untuk memperkuat konseptual legitimasi, bangunan fungsional, teori structural - fungsional, teori sistem terbuka, dan teori institusional berbasis luas dan mengakui evaluasi, kognisi, dan konstruksi sosial. Legitimasi didefinisiskan sebagai persepsi umum atas tindakan entitas yang dapat diterima dan diinginkan, tepat, atau sesuai dengan karakteristik perusahaan yang dibangun atas dasar norma, nilai-nilai, dan keyakinan bersama. Kontribusi legitimasi stakeholder tergantung pada interaksi dengan dua atribut lainnya: power dan urgensi, keuntungan legitimasi melalui power dan voicenya melalui urgensi.

Legitimasi perusahaan merupakan persepsi general bahwa perusahaan berperilaku tepat menurut beberapa definisi budaya perusahaan. Legitimasi secara obyektif diselenggarakan oleh perusahaan dan independen pengamat tertentu, tetapi atribusi individu legitimasi mencerminkan keyakinan individu bahwa orang lain yang relevan melihat "sebuah congruence antara perilaku perusahaan dan keyakinan".
Lokalitas budaya perusahaan akan mecerminkan citra perusahaan, normanorma, dan nilai-nilai budaya yang disosialisasikan.

Perusahaan memperoleh legitimasi sesuai dengan tekanan institusional. Kesesuaian membuat menjadi mirip satu sama lain. Merujuk pada tiga sumber tekanan institusional. Tekanan koersif berasal dari tindakan negara, misalnya dengan memberlakukan peraturan lingkungan, tekanan koersif memiliki relevansi marginal karena peraturan lingkungan. Tekanan normatif timbul dari aktivitas profesi dan asosiasi profesional, yang memainkan peran aktif dalam penyebaran praktik pengelolaan lingkungan. Tekanan mimesis melibatkan imitasi dari praktek yang digunakan oleh perusahaan lain dalam industri, terutama yang dianggap berhasil. Misalnya saja dalam industri hotel, jaringan pariwisata berdifusi dengan praktek manajerial yang sukses dan bertindak sebagai enabulasi pembelajaran perusahaan.

Legitimasi sebagai sumber daya perusahaan atau sebagai keselarasan dengan hukum atau norma-norma yang menonjol. Legitimasi akan diperoleh perusahaan sepanjang mereka memenuhi harapan kelompok yang relevan dalam pengaturan khusus mereka. Perusahaan dapat memperoleh legitimasi dengan menghubungkan praktik tanggung jawab sosial terhadap kinerja keuangan.

Perusahaan harus membedakan antara legitimasi sosial dan legitimasi ekonomi. Perusahaan yang melakukan kegiatan perlindungan lingkungan atas dasar mempertahankan tingkat harga tanggung jawab sosial, menunjukkan power pendorong kegiatan untuk menhasilkan dampak positif yang diharapkan terhadap kinerja keuangan. Pendekatan ini disebut dengan pendekatan 
pengelolaan lingkungan yang terkait dengan model peran stakeholder.

Model peran stakeholder berpendapat bahwa stakeholder perusahaan berada dalam lingkungan yang lebih luas yang menuntut ambang kinerja keuangan. Pendekatan ini memiliki dua implikasi tambahan. Pertama, membatasi perspektif stakeholder untuk salah satu konstituen korporasi, yaitu: para pemegang saham. Kedua, minat perusahaan dalam hubungan stakeholder menjadi sangat tergantung pada dampaknya pada kesuksesan finansial. Misalnya, kepatuhan bisnis dengan tuntutan lingkungan stakeholder dikaitkan dengan niat untuk meningkatkan keunggulan kompetitif.

Teori stakeholder juga mengasumsikan bahwa korporat mengadopsi praktek manajemen lingkungan untuk menyelaraskan strategi secara keseluruhan dengan normanorma dan keyakinan lingkungan. Dalam melakukannya, legitimasi sosial perusahaan dapat diterima sepanjang memenuhi tujuan sosial. Pendekatan ini diberi label sebagai model intrinsik dan menyiratkan minat yang tulus pada bagian dari perusahaan untuk memenuhi kepentingan dan mengkoordinasikan kepentingan kelompok stakeholder yang beragam. Pendekatan ini dapat diterima jika bersesuaian dengan tuntutan lingkungan stakeholder yang mencerminkan komitmen moral untuk mencapai pengakuan sosial melalui perlindungan kepentingan umum, yaitu lingkungan walaupun komitmen tersebut belum tentu terkait dengan alasan keuangan.

Model peran yang dianggap sebagai pelengkap. Kesesuaian perusahaan dengan tekanan yang berasal dari konteks kelembagaan yang lebih luas (misalnya negara yang memberlakukan peraturan lingkungan) menginvestasikan perusahaan yang bersangkutan dengan legitimasi, tetapi juga dapat membayar dalam hal keuangan.
Dengan mematuhi tekanan tersebut, akan menghindarkan perusahaan yang tidak hanya kerugian finansial yang timbul dari denda atau penutupan sementara operasi sampai investasi lingkungan tambahan yang dibuat, tetapi juga kerugian yang bersifat intangible (low profile dalam pengelolaan lingkungan).

\section{Urgensi}

Urgensi bukanlah atribut mapan tetapi dapat berbeda-beda dalam hubungan stakeholder-manager. Seperti halnya power dan legitimasi, urgensi adalah fenomena persepsi yang dibangun secara sosial dan dapat dianggap benar atau palsu oleh stakeholder, manajer, atau yang lainnya di lingkungan perusahaan.

Urgensi tidak dengan sendirinya menjamin arti penting hubungan stakeholdermanager. Namun, ketika dikombinasikan dengan salah satu atribut lainnya, akan mengubah hubungan dan menyebabkan peningkatan arti penting bagi manajer perusahaan. Secara khusus, dalam kombinasi dengan legitimasi, urgensi mempromosikan akses ke saluran pengambilan keputusan, dan dalam kombinasi dengan power, mendorong satu sisi aksi stakeholder. Dalam kombinasi kedua, urgensi memicu pengakuan timbal balik dan tindakan antara stakeholder dan manajer tidak statis, melainkan berada dalam bentuk konstan.

Ketika power dan legitimasi dalam hubungan stakeholder-manajer dimana urgensi didefinisikan dengan sinonim "menarik, mengarah, dan penting," dalam dua kondisi terpenuhi: (1) ketika hubungan atau klaim bersifat sensitif terhadap waktu dan (2) hubungan itu penting. Dengan demikian, deskripsi intensitas moral sebagai urgensi muncul dalam sensitivitas waktu: (1) keterlambatan manajerial merespon klaim, dan (2) pentinnya hubungan dengan 
stakeholder menjadi penentu dapat atau tidaknya diterima oleh stakeholder

Gagasan berbagai hubungan stakeholder - manajer secara tepat waktu menjadi fokus isu manajemen dan akademisi manajemen menyoroti kecepatan dapat menjadi simbol peran penting dalam menciptakan urgensi waktu. Komitmen waktu dan mobilisasi karyawan terhadap beberapa ancaman dari luar, bagian penting dari penggunaan power.

Sensitivitas waktu dalam perusahaan diperlukan, dan klaim hubungan stakeholder - manajer dalam perusahaan sebagai masalah kritis atau sangat penting. Beberapa contoh mengapa stakeholder melihat hubungannya dengan perusahaan dalam hal berikut:

1. Kepemilikan: kepemilikan stakeholder terhadap aset perusahaan yang spesifik, atau aset-aset terkait dengan perusahaan yang tidak dapat digunakan dengan cara yang berbeda tanpa kehilangan nilai, sehingga sangat mahal bagi stakeholder untuk keluar dari hubungan itu;

2. Sentimen: seperti dalam kasus saham dengan mudah diperdagangkan yang dipegang oleh pemilik dalam sebuah keluarga, terlepas dari kinerja saham itu sendiri;

3. Ekspektasi: antisipasi stakeholder bahwa perusahaan akan terus menyediakan sesuatu yang bernilai besar (misalnya, kompensasi dan tunjangan karyawan); atau

4. Exposure: pentingnya stakeholder memahami resiko dalam hubungan dengan perusahaan.

\section{Atribut Teori Stakeholder}

Dimensi teoritis stakeholder dianggap penting dalam proses bisnis terutama karena masing-masing memiliki karakteristik spesifik yang mampu memberikan pengaruh yang berbeda (1) Dormant Satakeholder (Power), Discretionary Stakeholder (Legitimacy), dan Demanding Stakeholder (Urgency) memiliki pengaruh rendah karena masing-masing dengan satu atribut atau dimensi, (2) Dominant, Dangerous dan Dependent Stakeholder dengan dua dimensi (Power dan Urgensi atau Powwer dan Legitimacy, atau Urgency dan Legitimacy) memiliki pengaruh medium, dan (3) Definitive Stakeholder merupakan kombinasi atribut Power, Legitimacy dan Urgency memiliki pengaruh tinggi. Secara terpisah masing-masing dimensi memberikan implikasi yang berbeda dalam perusahaan

\section{Dormant Stakeholders}

Dimensi yang relevan dari dormant stakeholder adalah power. Dormant stakeholder memiliki power untuk memaksakan kehendak mereka pada perusahaan, tetapi ketika dormant stakeholder ini tidak memiliki hubungan yang sah, power mereka tetap tidak terpakai. Dormant stakeholder memiliki sedikit atau tidak ada interaksi dengan perusahaan. Namun, karena potensi mereka untuk memperoleh atribut tertentu, manajemen harus tetap hati-hati terhadap stakeholder seperti itu, karena sifat dinamis dari hubungan stakeholder-manager menunjukkan bahwa dormant stakeholder akan menjadi lebih menonjol ke manajer, jika mereka memperoleh urgensi atau legitimasi. Meskipun sulit, untuk memprediksi dormant stakeholder dapat menjadi menonjol. Misalnya saja karyawan yang telah dipecat atau diberhentikan dapat dianggap oleh perusahaan menjadi dormant stakeholder, dormant stakeholder ini dapat berusaha menjalankan power laten mereka.

\section{Discretionary Stakeholders.}

Discretionary stakeholder memiliki atribut legitimasi, tetapi mereka tidak 
memiliki power untuk mempengaruhi perusahaan. Discretionary stakeholder adalah kelompok yang sangat menarik bagi para akademisi manajemen, tanggung jawab sosial perusahaan dan kinerja, karena mereka yang paling mungkin untuk menjadi penerima tanggung jawab sosial perusahaan, yang kemudian didefinisikan ulang sebagai filantropi perusahaan. Dalam discretionary stakeholder power tidak muncul, tidak ada tekanan pada manajer untuk terlibat dalam hubungan aktif dengan stakeholder, meskipun manajer dapat memilih untuk melakukannya dan hanya stakeholder yang memiliki power yang baik terhadap perusahaan yang menerima filantropi perusahaan.

\section{Demanding Stakeholders}

Dimensi yang relevan menunjukkan hubungan stakeholder dengan manager adalah urgensi, stakeholder digambarkan sebagai demanding. Menuntut para stakeholder yang tidak memiliki power atau legitimasi, menjengkelkan tapi tidak berbahaya, mengganggu tapi menjamin perhatian manajemen, Stakeholder tidak mampu atau tidak mau memperoleh baik power atau legitimasi yang diperlukan untuk memindahkan klaim mereka ke status yang lebih menonjol, Voice urgensi tidak cukup untuk memproyeksikan klaim pihak luar.

\section{Dominant Stakeholders}

Dalam situasi di mana para stakeholder kuat dan sah, pengaruh mereka di perusahaan terjamin, karena dengan memiliki power dan legitimasi mereka membentuk :"koalisi dominan" dalam perusahaan. Ciri takeholder ini adalah "dominan" dalam merespon klaim perusahaan dan kemampuan mereka untuk bertindak atas klaim tersebut. Stakeholder yang dipersepsikan oleh manajer adalah memiliki power dan legitimasi.
Stakeholder yang dominan memiliki beberapa mekanisme formal dalam mengakui pentingnya hubungan mereka dengan perusahaan. Perusahaan dengan dominant stakeholder biasanya menyediakan kantor investor untuk menangani keberlanjutan hubungan dengan investor, memiliki departemen SDM yang mengakui pentingnya hubungan perusahaan dengan karyawan, dan departemen publik service untuk mempertahankan hubungan baik dengan konsumen, masyarakat dan pemerintah.

\section{Dangerous Stakeholders}

Urgensi dan power yang tidak memiliki legitimasi, stakeholder akan memaksa dan mungkin kekerasan, membuat stakeholder "berbahaya," bagi perusahaan. "Pemaksaan" dengan penggunaan power sering menyertai keabsahan status mereka. Contoh upaya melanggar hukum seperti informasi palsu, pemogokan, sabotase karyawan, dan terorisme. Aksi stakeholder ini tidak hanya berada di luar batas-batas legitimasi tetapi juga berbahaya, baik untuk hubungan stakeholder-manajer dan maupun hubungan individu dan entitas yang terlibat. Sangat tidak nyaman dengan gagasan aksi yang berbahaya, baik untuk hubungan stakeholdermanager serta kehidupan dan kesejahteraan semua mitra bisnis. Kegagalan mengidentifikasi para dangerous stakeholders ini akan mengakibatkan hilangnya kesempatan untuk mitigasi bahaya

\section{Dependent stakeholders}

Stakeholder ini kurang power tetapi memiliki klaim yang sah sebagai dependent stakeholders, para stakeholder ini tergantung pada orang lain (stakeholder lain atau manajer perusahaan) yang diperlukan untuk melaksanakan kehendak mereka. Karena power kurang, maka power mereka diatur melalui advokasi atau perwalian stakeholder lainnya, atau melalui bimbingan nilai-nilai 
manajemen internal. Beberapa kelompok stakeholder yang memiliki sedikit atau tidak ada power untuk menegakkan keinginan mereka dalam hubungannya dengan perusahaan, stakeholders ini bergantung pada advokasi lainnya, atau pada stakeholder yang kuat atau pada voluntarisme manajemen perusahaan.

\section{Definitive Stakeholders}

Pengaruh stakeholder akan tinggi ketika semua atribut stakeholder : power, legitimacy, dan urgensi dapat dirasakan oleh manajer. Stakeholder yang menunjukkan power dan legitimasi akan menjadi anggota koalisi dominan sebuah perusahaan. Saat klaim stakeholder sangat kuat, manajer memiliki mandat yang jelas dan langsung untuk menghadiri dan memberikan prioritas kepada klaim stakeholder. Kejadian yang paling umum adalah gerakan stakeholder yang dominan dalam kategori "definitif" akan menghasilkan pengarh yang tinggi.

\section{PENGARUH POWER STAKEHOLDER}

Bagi manajer, stakeholder adalah penonton yang memiliki pengaruh langsung terhadap kinerja dan kelangsungan hidup perusahaan. Tingkat relatif perhatian manajer adalah “membayar" kebutuhan, keyakinan, nilai-nilai dan tingkat ketanggapan terhadap variasi demands stakeholder. Dalam integrasi teori dependence sumber daya dan teori institu-sional, spesifikasi korporat yang disetujui, ditolak, atau pengaruh proaktif eksternal dan tuntutan akan terjadi interkoneksi antar anggota jaringan perusahaan yang membuat komunikasi yang lebih efisien dan fasilitasi pertukaran informasi melalui jaringan sehingga normanorma dan harapan menyebar dan terlembagakan (Donaldson, Thomas and Lee 1995).
Hasil validasi para manajer menunjukkan bahwa pengaruh stakeholder terhadap kinerja bisnis sangat ditentukan oleh (1) power stakeholder terhadap korporasi, (2) power stakeholder terhadap tekanan ekternal, (3) Power stakeholder terhadap kebijakan perusahaan (4) jaringan stakeholder (5) komitmen intrinsik dan outcomes bisnis, dapat dijelaskan sebagai berikut :

\section{Power Stakeholder Terhadap Korporasi \\ Di antara teori-teori kelembagaan,} ketergantungan sumber daya dan jaringan menunjukkan pada bagaimana aktor sosial tertentu dalam lingkungan mempengaruhi perusahaan. Korporasi tidak "mandiri", lingkungan harus dikelola agar mereka memberikan dukungan, mereka akan menunjukkan apa yang dibutuhkan perusahaan, ini adalah fakta ketergantungan perusahaan terhadap lingkungan (stakeholders eksternal) untuk membuat kendali atas kendala eksternal dan kontrol perilaku perusahaan yang tidak terelakkan. Pertentangan kepentingan stakeholder dan perusahaan akan membentuk model interaksi stakeholder-perusahaan adalah inti dari teori stakeholder. Penyimpangan kepentingan dan perusahaan tidak bersedia mengubah perilaku untuk mengakomodasi stakeholder akan mempengaruhi kinerja perusahaan

Ketergantungan sumber daya dari satu pelaku ditandai dengan (1) konsentrasi (jumlah pemasok sedikit), (2) pengendalian, (3) nonmobilitas, (4) nonsubstitusi, ( 5) esensialitas. Esensialitas sumber daya itu sendiri merupakan fungsi dari faktor: (1) pertukaran relatif dan (2) kekritisan. Besarnya pertukaran dilakukan dengan persentase input/output. Jika A memasok sebagian besar pasokan ke perusahaan B, atau menyerap sebagian besar output dari A, maka B akan tergantung pada A. Kekritisan 
sumber daya berkaitan dengan apakah perusahaan $\mathrm{B}$ dapat eksis tanpa perusahaan A. Artinya bahwa perusahaan B memerlukan stakeholder lain - stakeholder A.

\section{Power stakeholder terhadap tekanan ekternal}

Power membawa beberapa pertimbangan yang menarik ke dalam hubungan antara para stakeholder dan kebijakan lingkungan eksternal perusahaan yaitu power dan penggunaan power stakeholder dalam mempengaruhi kegiatan lingkungan eksternal perusahaan melalui berbagai strategi atau pengaruh yang dimiliki oleh stakeholder. Tekanan dari para stakeholder mungkin akan diterima atau mungkin ditolak tergantung pada kapasitas dan kepemilikan power stakeholder dalam menjelaskan keputusan perusahaan terkait dengan kepentingan khusus peru-sahaan. Secara khusus, bahwa kepentingan stakeholder dalam isu-isu pengelolaan lingkungan eksternal perusahaan dapat membuat dampak keputusan korporasi lebih langgeng, terutama ketika stakeholder memiliki power yang kuat.

\section{Power stakeholder terhadap kebijakan perusahaan}

Penggunaan stakeholder dianggap memiliki power jika energy pendorong atau pengaruh pada keputusan perusahaan, termasuk terhadap pengelolaan lingkungan eksternal perusahaan. Stakeholder dapat mempengaruhi manajemen perusahaan melalui berbagai mekanisme seperti insentif, denda, saran, dan sejauh mana stakeholders menggunakan mekanisme pengaruh yang tidak hanya tergantung pada pentingnya isuisu bisnis, tetapi juga pada sejauh mana stakeholder itu merasa bahwa perusahaan memiliki kapasitas dan / atau tanggung jawab untuk mengurangi dampak negatif dari sebuah kebijakan perusahaan terhadap kegiatan bisnis.

\section{Power Jaringan Stakeholder}

Kepadatan jaringan stakeholder (jumlah hubungan dalam jaringan yang menghu-bungkan para anggota secara bersama-sama) meningkat, bersama harapan perilaku muncul di antara semua anggota, dan fokus tindakan korporasi untuk menjadi meningkat dibatasi oleh norma. Jaringan padat menghasilkan tekanan stakeholder yang lebih terpadu, kuat dan korporat bergerak ke arah konformitas yang lebih dinamis (Klijn, \& Edelenbos, 2010).

Rekonstruksi citra manajerial perusahaan yang diinginkan akan sangat dipengaruhi oleh persepsi manajer dari kebutuhan stakeholder, nilai-nilai, keyakinan, dan isi dari identitas perusahaan cenderung mencerminkan struktur yang dilembagakan dan proses didukung oleh jaringan. Karena ketidaksesuaian kemungkinan secara keseluruhan reaksi para stakeholder akan negatif, manajer perlu terlibat dalam pengolahan informasi stakeholder, pemantauan dan penilaian normatif atas mereka.

Jaringan dengan norma-norma perilaku ber-sama yang kurang, stakeholders lebih mungkin untuk memiliki ekspektasi bertentangan dengan perusahaan. Manajer perlu mendengarkan voice, memperhatikan tuntutan nilai, keyakinan, dan kebutuhannya, ini memungkinkan manajer untuk menghindari, menentang, atau memanipulasinya daripada menyetujui tuntutan stakeholder yang tidak rasional.

Sentralitas sebuah perusahaan dalam jaringan stakeholder juga mempengaruhi sejauh mana perusahaan dapat menghindari kebutuhan stakeholder. Sentralitas mengacu pada power aktor informal dalam jaringan sebagai akibat dari jabatan struktural relatif terhadap aktor-aktor lain dalam jaringan. Ketika perusahaan fokus pada total pengaruh jaringan, peru-sahaan memiliki lebih banyak sumber potensial dalam mengembangkan 
citra perusa-haan yang diinginkan, lebih memperhatikan stakeholder yang dianggap menjadi kuat dan memiliki klaim yang sah dan logis.

Ekspektasi stakeholder yang memiliki dua dari tiga atribut menimbulkan pengolahan informasi kurang efektif, sebalikinya stakeholder laten yang memiliki klaim atau legitimasi atau power yang baik akan akan dalam pembangunan citra perusahaan. Manajer cenderung untuk menyajikan citra perusahaan yang diinginkan para stakeholder yang sebagian besar dari komponen sejarah identitas, dengan kurang memperhatikan kebutuhan stakeholder saat ini, model, atau persepsi mereka.

Bagaimana korporasi membedakan perhatiannya terhadap stakeholder, dapat dilakukan dengan dua cara: Pertama; perusahaan besar, mapan, perusahaan multinasional dengan layanan kastemisasi dan perhatian individual. Kedua, pasar massal, dengan interaksi yang tidak secara spesifik terkait dengan isu power, legitimasi, atau urgensi, oleh karena itu :

a. Semakin banyak jaringan stakeholder, semakin besar pengaruh kebutuhan stakeholder, values, dan keyakinan akan di rekonstruksi manajer dari identitas perusahaan.

b. Semakin besar sentralitas persepsi perusahaan dalam jaringan stakeholder, semakin kurang pengaruh kebutuhan stakeholder, nilai-nilai, dan keyakinan akan di rekonstruksi manajer dari identitas perusahaan.

c. Sejauh manajer menganggap stakeholder itu kuat, sah, dan memiliki klaim yang logis, maka kebutuhan, nilai, dan keyakinan stakeholder akan lebih besar dalam membangun citra perusahaan yang diinginkan.

d. Identifikasi power perusahaan akan positif terkait dengan persepsi stakeholder terhadap urgensi klaim mereka.

Membangun identitas merek atau ekuitas merek sering dirancang dengan mengembangkan dan mendiskripsikan identitas perusahaan baik membangun keseluruhan citra perusahaan atau dukungan atas kebijakan dan program perusahaan. Merek perusahaan atau produk dipengaruhi oleh citra dan reputasi dan pada akhirnya akan mempengaruhi cara konsumen dalam mempersepsi merek. Ini adalah inti dari identitas perusahaan.

Urgensi dipengaruhi oleh pemahaman manajer. Power stakeholder meningkat, aksesibilitas dan identitas sosial perusahaan meningkat, dan identitas sosial menjadi lebih penting bagi stakeholder. Dengan meningkatnya urgensi, para stakeholder akan melihat klaim mereka pada perusahaan lebih logis, dan mereka cenderung menekan klaim ini menjadi lebih aktif untuk manajer perusahaan.

a. ketika manajer dapat bekerja pada tingkat identifikasi stakeholder yang tepat, akan membantu manajer dalam menentukan siapa stakeholder perusahaan yang sebenarnya, dan upaya TM untuk mengelolanya akan lebih realistis.

b. tantangan mengelola tuntutan stakeholder menjadi lebih jelas ketika minat mereka dalam strategi perusahaan dipisahkan dari power mereka untuk mempengaruhi hasil dari sebuah strategi. Pemisahan ini menciptakan tiga kategori penting yang dapat membantu TM memahami sejumlah besar stakeholder: stakeholders dengan minat tertentu tapi powernya kecil, stakeholder dengan power besar tetapi interesnya kecil, dan stakeholder yang memiliki keduanya (pemain utama). 
c. jaringan formal, dan informal, hubungan antara stakeholder mengungkapkan aspek penting dari power mereka. Beberapa stakeholder bertindak atas dasar hubungan tersebut, dan biasanya lebih kuat daripada antisipasi manajer.

d. hubungan formal biasanya lebih mudah dipahami dan rasional, sedangkan hubungan informal biasanya sering terbentuk oleh ikatan emosional, dan karenanya sering menjadi lebih signifikan.

e. pengaruh jaringan stakeholder akan sangat spesifik untuk perusahaan yang lebih fokus, dan dapat melibatkan sensitifitas manajer.

Setiap perusahaan menghadapi karakteristik stakeholder yang berbeda, pola pengaruh yang unik dan jaringan yang spesifik dapat menunjukkan di mana dukungan diperlukan untuk menciptakan, mempertahankan dan memenangkan koalisi stakeholder. Jaringan juga membantu TM untuk lebih mengerti, meletakkan mana pemain yang penting dan mana hubungan yang paling jelas. Jaringan menggambarkan hubungan antara stakeholder dengan perusahaan, arah yang menunjukkan sifat hubungan dan di mana mereka saling mempengaruhi akan berdampak pada kinerja perusahaan.

\section{Power intrinsik dan Outcomes Bisnis}

Komitmen intrinsik stakeholder, hubungan manajerial dengan para stakeholder berdasarkan normatif, komitmen moral bukan pada keinginan untuk menggunakan stakeholder semata-mata untuk memaksimalkan keuntungan, tetapi menetapkan prinsip-prinsip dasar moral tertentu yang memandu bagaimana melakukan bisnis, khususnya yang berkaitan dengan bagaimana memperlakukan stakeholder dan menggu- nakan prinsip-prinsip tersebut untuk mendorong pengambilan keputusan.

Jika komitmen intristik stakeholder dalam membuat keputusan perusahaan memiliki dampak terhadap outcomes bisnis yang pada umumnya dianggap etis, artinya bahwa kepentingan stakeholder memiliki nilai intrinsic dan klaim stakeholders didasarkan pada prinsip-prinsip moral yang tidak terkait dengan nilai instrumental stakeholder terhadap perusahaan, dan jika sebaliknya dianggap tidak etis

Perusahaan tidak dapat mengabaikan komitmen intristik stakeholder hanya karena menghormati mereka kemudian tidak melayani kepentingan strategis, independensi dan pertimbangan strategis perusahaan. Kepentingan stakeholder akan membentuk dasar strategi korporasi dalam mewakili statement "apa yang sedang diperjuangkan" oleh perusahaan.

Orientasi teori normatif adalah membuat komitmen strategis untuk bertindak sesuai dengan prinsi-prinsip moral untuk memperoleh reputasi yang baik, yang pada gilirannya, akan memberikan manfaat ekonomi bagi perusahaan dan manfaat instrumental manajemen stakeholder bersumber dari komitmen terhadap prinsipprinsip etika, perusahaan menciptakan dan mempertahankan hubungan stakeholder berdasarkan saling percaya dan kerja sama akan menghasilkan keunggulan kompetitif dibanding yang tidak.

Jika komitmen, kepercayaan kejujuran, integritas dan kerjasama strategis antara manajemen dengan stakeholder tidak ada atau palsu, perusahaan akan sulit mempertahankan reputasi yang diperlukan dalam membangun kemitraan ekonomi. Dengan demikian, dalam rangka untuk menuai keuntungan instrumental manajemen stakeholder, perusahaan harus berkomitmen untuk membangun hubungan etis dengan 
para stakeholder terlepas dari keuntungan yang diharapkan. Komitmen strategis yang diterapkan tidak benar-benar secara moral, perusahaan tidak dapat mengarah pada hasil strategis yang diinginkan.

Komitmen stakeholder memiliki nilai intrinsik bagi keputusan strategis perusahaan dan membentuk dasar moral bagi strategi perusahaan itu sendiri. Komitment intrinsik stakeholder dan komitmen manajerial akan mendorong pembuatan keputusan yang lebih strategis, yang pada gilirannya akan mempengaruhi kinerja keuangan perusahaan, strategi memediasi hubungan antara stakeholder dan kinerja keuangan perusahaan.

\section{Harmonisasi Manajemen dan Stakeholder}

Mengacu pada kepentingan perusahaan dalam hubungannya dengan stakeholder sebagai instrumental dan bergantung pada nilai hubungan untuk peningkatan keuangan perusahaan. Stakeholder menjadi Instrumental strategis untuk memaksimalkan kekayaan perusahaan. Manajemen stakeholder merupakan bagian dari strategi perusahaan, dan hubungan korporasi dengan stakeholders masuk ke dalam kalkulasi strategis, dan jenis hubungan yang menghasilkan outcomes terbaik bagi perusahaan, maka manajemen stakeholder harus sepenuhnya compatible dengan tanggung jawab bisnis yaitu meningkatkan keuntungan.

\section{Hubungan manajemen dengan Stakeholder \\ Terminologi hubungan antara} perusahaan (manajemen) dengan stakeholder merupakan hubungan dua arah yang berguna dalam pencapaian tujuan perusahaan, dalam dua hal: Pertama, jika stakeholders mempengaruhi pencapaian tujuan korporasi, maka kinerja perusahaan dipengaruhi oleh stakeholder. Hubungan ini menunjukkan postur stakeholder berperan dalam perusahaan dan perlu mengelola stakeholder untuk memaksimalkan keuntungan. Kedua, jika para stakeholder dipengaruhi oleh capaian tujuan perusahaan, berarti bahwa perusahaan mempengaruhi kesejahteraan para stakeholder, yang pada gilirannya menunjukkan kemungkinan kewajiban normatif kepada para stakeholder pada perusahaan. Artinya, manajer mungkin merasa bahwa mereka memiliki kewajiban moral yang mendasar kepada para stakeholder dengan alasan pendekatan manajerial (Takis and Yannis, 2007).

\section{Penyatuan Kepentingan}

Manajemen korporat muncul dari penyatuan individu dan terorganisir dengan tuntutan yang berbeda, mengubah fokus perhatian, dan kemampuan yang terbatas untuk mengelola semua masalah secara bersamaan", di bawah ketidakpastian, harus mencari umpan balik dari lingkungan korporat sebagai penyatuan dari berbagai kepentingan dan kontribusinya diarahkan, dipengaruhi oleh pelaku yang Mengendalikan sumber daya (manajer). Manajer memiliki tanggung jawab untuk menyeimbangkan kepentingan yang berbeda dengan membuat keputusan strategik dan mengalokasikan sumber daya strategis dalam cara yang paling konsisten dengan klaim stakeholder.

Seberapapun besarnya saham mereka, masing-masing stakeholder merupakan bagian dari yang menghubungkan kontrak implisit dan eksplisit korporasi. Manajer adalah satu-satunya kelompok stakeholder yang masuk ke dalam hubungan kontrak dengan semua stakeholders lainnya. Manajer juga satu-satunya kelompok stakeholder dengan kontrol langsung atas pengambilan keputusan perusahaan. Stakeholder berdasarkan kepemilikan power, legitimacy, dan urgensi dalam hubungannya dengan 
perusahaan, jika manajer perusahaan melihat stakeholder itu penting dan karena itu mereka akan memperoleh perhatian manajemen, demikian juga sebaliknya, artinya sangat tergantung pada persepsi manajer (penting atau tidak) terhadap atribut stakeholder. Perbedaan dalam nilai manajerial adalah gambaran efek moderasi dari karakteristik manajemen.

\section{Reaksi Manajemen}

Nilai-nilai relatif manajer memiliki efek yang kuat pada bagaimana mereka bereaksi terhadap stakeholder. Teori nilai menjadi penting dalam hubungannya dengan perilaku manajemen apakah untuk kepentingan pribadi, atau menguntungkan orang lain dengan merugikan diri sendiri. Pertimbangannya adalah: Pertama, bahwa manajer ingin mencapai tujuan tertentu dengan memperhatikan berbagai kelas stakeholder; Kedua, persepsi manajer tentang urgensi stakeholder; dan Ketiga, berbagai kelas stakeholder mungkin diidentifikasi berdasarkan kepemilikan, atau dikaitkan dengan satu, dua, atau tiga atribut: power, legitimasi, dan urgensi. Dalam hubungannya dengan persepsi manajer dalam menentukan alokasi sumber daya perusahaan, pengaruh stakeholder akan positif jika power, legitimasi, dan urgensi dapat dirasakan oleh manajer. sebaliknya akan negatif.

\section{Pengambilan Keputusan}

Model hubungan stakeholder dengan manajemen stakeholder strategis dalam proses pengambilan keputusan perusahaan diakui jika memiliki nilai strategis untuk koneksi perusahaan dan kinerja perusahaan. Artinya, manajer hanya peduli dan melayani kepentingan pemegang saham dan stakeholder lainnya sebagai sarana untuk mewujudkan tujuan itu. Efek langsung, sikap dan tindakan terhadap para stakeholder, persepsi manajer memiliki efek langsung dari independensi strategi perusahaan terhadap kinerja keuangan. Moderasi, dan orientasi manajerial terhadap stakeholder dan hubungan antara strategi mempengaruhi kinerja keuangan perusahaan.

\section{Startegi Korporasi}

Strategi tingkat perusahaan menunjukkan bahwa kelangsungan hidup perusahaan tergantung kepada kepada kecocokan nilai-nilai korporasi dan manajer, harapan stakeholder dan isu-isu sosial yang akan menentukan perusahaan dan kemampuan perusahaan untuk menjual produk-produknya. Tujuan akhir dari keputusan strategi tingkat perusahaan adalah kesuksesan pasar. Perusahaan melihat stakeholders mereka sebagai bagian dari lingkungan yang harus dikelola untuk menjamin pendapatan, keuntungan, dan return pemegang saham.

Perhatian terhadap kekhawatiran stakeholder dapat membantu keputusan yang menghindari perusahaan dari kemungkinan stakeholder untuk melemahkan atau menggagalkan tujuannya, terutam karena para stakeholder mengendalikan sumber daya yang dapat memfasilitasi atau meningkatkan pelaksanaan keputusan korporat; Manajemen stakeholder adalah alat untuk mencapai tujuan akhir, atau hasil akhir, mungkin tidak ada hubungannya dengan kesejahteraan stakeholders pada umumnya. Sebaliknya, tujuan perusahaan adalah kemajuan untuk kepentingan satu pemegang saham stakeholder.

\section{Kontrol Strategis}

Pelaku usaha yang menyediakan sumber daya untuk sebuah perusahaan dengan dua kontrol atas perusahaan: (1) pembatasan untuk mendapat sumber daya yang dibutuhkan (menutup aliran sumber daya) dan (2) penggunaan sumber daya yang diinginkan. 
a. Strategi Pembatasan

Diskresi atas

diterjemahkan ke strategi pengaruh stakeholder yang memilih untuk tidak mengalokasikan (menahan sumber daya). Strategi pembatasan di mana stakeholder diskontinus menyediakan sumber daya untuk sebuah perusahaan dengan tujuan membuat perubahan perilaku korporasi (tertentu). Setiap stakeholder menyediakan sumber daya untuk perusahaan memiliki metode pembatasan yang berbeda. Misalnya, menahan tenaga kerja, dan menahan pembiayaan utang, dan boikot pelanggan untuk mempengaruhi keputusan perusahaan.

\section{b. Strategi Penggunaan}

Strategi penggunaan menunjukkan dimana stakeholder secara terus menerus memasok sumber daya, tetapi dengan pamrih. Ini bisa terjadi ketika stakeholder dan perusahaan saling bergantung dan tidak berada dalam posisi hubungan, mereka akan melakukannya dengan atas dasar kesesuain kebutuhan masing-masing.

\section{Ketergantungan}

Power dalam ketergantungan sumber daya timbul dari hubungan dengan orang lain (partner atau mitra eksternal stakeholder) yang memasok sumber daya perusahaan. Jalur pengaruh stakeholder digunakan untuk melakukan kontrol sumber daya baik secara langsung maupun tidak langsung. Strategi langsung menunjukkan bahwa stakeholder sendiri memanipulasi aliran sumber daya ke perusahaan (baik dengan menahan atau penggunaan). Strategi tidak langsung, misalnya menggunakan teori keagenan dalam memasok sumber daya perusahaan walaupun tidak ada hubungan formal diantara mereka, mereka hanya bekerja dalam kesebandingan kepentingan (value of money) mereka.

\section{a. Ketergantungan perusahaan.}

Korporasi akan responsif terhadap orang lain di lingkungan mereka yang menyediakan sumber daya yang berharga, teori ketergantungan sumber daya menunjukkan bahwa perilaku korporasi dipengaruhi secara eksternal karena perusahaan berada di lingkungan yang menyediakan sumber daya yang diperlukan dan penting untuk bertahan dan keberlanjutan hidup perusahaan. Korporat akan lebih respon terhadap tuntutan lingkungan yang mengendalikan sumber daya kritis. Rendahnya tingkat ketergantungan perusahaan terhadap stakeholder menyiratkan bahwa perusahaan tidak perlu responsif terhadap stakeholder. maka perusahaan relative dapat bertahan terhadap pengaruh stakeholder, stakeholder akan cenderung menggunakan strategi tidak langsung dalam mempengaruhi perusahaan.

\section{b. Ketergantungan Stakeholder.}

Ketergantungan terhadap sumber daya yang ada, berarti bahwa kesejahteraan perusahaan terkait dengan sumber daya kunci bagi perusahaan. Jika tingkat ketergantungan meningkat, kinerja perusahaan terikat dengan penyedia sumber daya, dan oleh karena itu, tingkat ketergantungan perusahaan yang tinggi terhadap stakeholder berarti bahwa kesejahteraan stakeholder juga terkait erat dengan kesejahteraan perusahaan. Stakeholder, tidak ingin melihat keberhasilan perusahaan terancam, dan karena itu, tidak akan memilih untuk menahan sumber daya yang penting bagi perusahaan, stakeholder akan cenderung menggunakan strategi 
penggunaan sebagai sarana pengaruhnya terhadap perusahaan.

c. Interdependensi hubungan

Ketika pertukaran entitas perusahaan adalah asimetris, ketergantungan perusahaan akan berkurang. Power ini dapat digunakan dalam upaya untuk mempengaruhi atau membatasi perilaku, dan jika pertukaran entitas perusahaan adalah simetris, dua korporat sama-sama bergantung pada satu sama lain, perusahaan tidak memiliki keunggulan dan menjadi lebih tergantung pada perusahaan, mengurangi kemungkinan bahwa salah satu perusahaan akan mendominasi pengaruh intercorporate, argumen ini menunjukkan tipologi hubungan (tabel 3). berdasarkan dependensi antara dua korporasi antara stakeholder dan perusahaan (Jones, et al, 2007).

Tabel 3. Interdependensi Power Stakeholder dan Power Perusahaan

\begin{tabular}{|l|c|c|c|}
\hline & Ketergantungan Stakeholder Pada Perusahaan \\
\hline Ketergantunga Perusahaan Pada Stakeholder & Tidak & Tidak & Yaw Interdependence \\
\hline & Ya & $\begin{array}{c}\text { Power Perusahaan } \\
\text { Power Stakeholder }\end{array}$ \\
Pigh Interdependence
\end{tabular}

Setiap ketergantungan hubungan berkisar pada rendah atau tinggi. Esensi penggunaan sumber daya sebagai kriteria untuk menentukan tingkat ketergantungan: Pertama, hubungan power stakeholder dan power perusahaan tidak ada ketergantungan sumber daya, ini menunjukkan hubungan saling ketergantungan rendah. Kedua, hubungan antara konsumen, sangat tergantung pada konsumen dalam memperoleh pendapatan penjualan. Konsumen tidak tergantung pada produk, dan kombinasi dependensi menunjukkan hubungan yang dicirikan sebagai salah satu power stakeholder. Ketiga, ketergantungan hubungan antara stakeholder dan perusahaan dan strategi stakeholder dalam mempengaruhi pengambilan keputusan perusahaan : (1) ketika salah satu hubungan saling ketergantungan rendah, stakeholder akan memilih strategi pembatasan langsung mempengaruhi perusahaan, (2) ketika hubungan ditandai dengan power korporasi, stakeholder akan memilih strategi penggunaan tidak langsung dalam mempengaruhi perusahaan, (3) ketika hubungan ditandai dengan power stakeholder, stakeholder akan memilih strategi pembatasan langsung dalam mempengaruhi perusahaan, dan (4) ketika salah satu hubungan saling ketergantungan tinggi, stakeholder akan memilih strategi penggunaan langsung dalam mempengaruhi perusahaan.

\section{POWER EKONOMI STAKEHOLDER DALAM BISNIS}

Dalam bisnis, stakeholder yang biasanya sebagai investor di perusahaan dimana tindakannya menentukan keputusan bisnis. Stakeholder tidak harus sebagai ekuitas pemegang saham. Mereka juga bisa menjadi karyawan, yang memiliki saham dalam keberhasilan perusahaan dan insentif bagi produk untuk sukses.

Setiap stakeholder yang memiliki power ekonomi dapat menjadi stakeholder definitif dengan mengakuisisi atribut yang hilang. Teori stakeholder menunjukkan bahwa jika mengadopsi unit analisis hubungan antara bisnis, kelompok-kelompok 
dan individu dapat mempengaruhi atau dipengaruhi, maka mereka memiliki kesempatan yang lebih baik dalam hal-hal berikut : Pertama, dari perspektif stakeholder, bisnis dapat dipahami sebagai seperangkat hubungan antara kelompokkelompok yang memiliki kepentingan dalam kegiatan yang membentuk bisnis. Ini adalah tentang bagaimana pelanggan, pemasok, karyawan, pemodal (pemegang saham, pemegang obligasi, bank, dll), masyarakat dan manajer berinteraksi untuk bersamasama menciptakan nilai perdagangan. Untuk memahami bisnis adalah mengetahui bagaimana hubungan ini bekerja dan berubah seiring waktu. Ini adalah tugas eksekutif untuk mengelola bentuk hubungan yang menciptakan nilai sebanyak mungkin bagi stakeholder dan untuk mengelola distribusi nilai tersebut, Kedua, ketika terjadi konflik kepentingan stakeholder, eksekutif harus menemukan cara untuk berpikir ulang sehingga kebutuhan kelompok stakeholder yang ditangani, dan sejauh nilai dapat dibuat untuk semua stakeholder. Jika pengorbanan harus dibuat, maka eksekutif harus mencari cara untuk membuat pengorbanan, dan kemudian bekerja pada peningkatan pengorbanan untuk semua pihak, Ketiga, meskipun manajemen bisa efektif dalam hubungan stakeholder untuk membantu bisnis bertahan hidup dan berkembang dalam sistem ekonomi tertentu tetap diletakkan dalam upaya moral karena menyangkut masalah nilai, pilihan, dan potensi bahaya serta manfaat bagi kelompok dan individu. Keempat, deskripsi manajemen yang memfokuskan perhatian pada penciptaan, pemeliharaan, dan keselarasan hubungan stakeholder yang dilenggkapi dengan praktisi bisnis untuk menciptakan nilai dan menghindari kegagalan moral.

Mereka bisa menjadi mitra bisnis, yang mengembangkan keberhasilan untuk menjaga rantai pasokan. Setiap bisnis membutuhkan pendekatan yang berbeda untuk para stakeholder. Peran stakeholder berbeda antara bisnis, tergantung aturan dan tanggung jawab mereka dalam perusahaan, oleh karena itu definisi yang paling umum dari stakeholder dalam konsep peran adalah orang- orang yang memiliki power paling layak dalap mempengaruhi kinerja perusahaan. Ackermann, and Eden (2011) menunjukkan bahwa definitive stakeholders menghasilkan kinerja yang tinggi. Dominant, dependent, dan dangerous stakeholder memiliki pengaruh moderat. Sementara dormant, discretionary, dan demanding stakeholder menghasilkan kinerja rendah (tabel 1).

\section{Tabel 1. Dampak Stakeholder Terhadap Kinerja Perusahaan}

\begin{tabular}{|l|c|c|c|c|}
\hline Jenis & Power & Legitimacy & Urgency & Kinerja Perusahaan \\
\hline Definitive & Yes & Yes & Yes & High \\
\hline Dominant & Yes & Yes & No & Medium \\
\hline Dependent & No & Yes & Yes & Medium \\
\hline Dangerous & Yes & No & Yes & Medium \\
\hline Dormant & Yes & No & No & Low \\
\hline Discretionary & No & Yes & No & Low \\
\hline Demanding & No & No & Yes & Low \\
\hline
\end{tabular}

\section{Nilai Bisnis}

Nilai bisnis sebuah perusahaan (value of the firm) merupakan kondisi tertentu yang telah dicapai oleh perusahaan yang menggambarkan kepercayaan masyarakat terhadap kegiatan perusahaan sejak 
perusahaan didirikan sampai dengan saat ini. Meningkatnya nilai perusahaan sesuai dengan keinginan para stakeholder dan pemiliknya, karena dengan meningkatnya nilai perusahaan, maka kesejahteraan para stakeholder dan pemilik juga akan meningkat (Harrison, Jeffrey and Wicks, 2013), artinya bahwa nilai perusahaan merupakan fenomena capaian kinerja bisnis yang sangat penting bagi komunitas internal bisnis. Semakin tinggi nilai perusahaan, kemakmuran stakeholder semakin tinggi.
Pemikiran ekonomi modern, terutama yang berkaitan dengan utilitas dan pengukuran nilai terikat dengan berbagai faktor: Nilai yang ditentukan oleh harga; nilai yang ditentukan oleh tenaga kerja; nilai yang ditentukan oleh pertukaran; dan nilai yang ditentukan oleh produksi (tabel 4) sebagai dimensi penting dari nilai baik bagi individu dan masyarakat, seperti penciptaan kemampuan untuk pengembangan diri dan kehidupan yang lebih baik.

\section{Table 2. Nilai-Nilai Bisnis}

\begin{tabular}{|c|c|c|}
\hline 1. & $\begin{array}{l}\text { Value in } \\
\text { exchange }\end{array}$ & $\begin{array}{l}\text { iilai didasarkan pada banyak item dalam pertukaran pasar, nilai dinegosiasikan } \\
\text { lan bersifat intersubjektif. }\end{array}$ \\
\hline 2. & Value of use & $\begin{array}{l}\text { ilai didasarkan pada evaluasi subjektif dari banyak item yang layak untuk } \\
\text { dividu tertentu; mungkin tidak terlihat oleh orang lain dan dapat bervariasi dari } \\
\text { ol sampai tak terbatas. }\end{array}$ \\
\hline 3. & $\begin{array}{l}\text { lue of } \\
\text { or }\end{array}$ & $\begin{array}{l}\text { lai didasarkan pada berapa banyak tenaga kerja yang diperlukan untuk } \\
\text { enciptakan nilai. Nilai ditentukan secara independen dari preferensi individu } \\
\text { an ditetapkan oleh kualitas yang melekat pada produk }\end{array}$ \\
\hline 4. & & $\begin{array}{l}\text { lai didasarkan pada total biaya yang digunakan untuk menghasilkan produk } \\
\text { perti nilai tenaga kerja, nilai diatur secara independen dari preferensi individu. }\end{array}$ \\
\hline 5. & $\begin{array}{l}\text { Intrinsic - } \\
\text { Extrinsic } \\
\text { Value: }\end{array}$ & $\begin{array}{l}\text { Salah satu cara untuk berpikir tentang nilai adalah apakah nilai intrinsik, atau } \\
\text { fitur yang melekat, dari item atau apakah itu hanya kendaraan atau sarana untuk } \\
\text { beberapa yang baik lainnya (ekstrinsik). Kebanyakan barang di pasar ekstrinsik } \\
\text { baik untuk memuaskan kebutuhan; uang membantu saya merasa penting atau } \\
\text { mengamankan barang yang memenuhi syarat sebagai barang yang memiliki nilai. }\end{array}$ \\
\hline 6. & $\begin{array}{l}\text { Subjective - } \\
\text { Objective } \\
\text { Value: }\end{array}$ & $\begin{array}{l}\text { Nilai subjektif mengacu pada penilaian individu dan apa yang terjadi, sementara } \\
\text { nilai obyektif mengacu pada norma yang beroperasi di seluruh individu atau pada } \\
\text { tingkat analisis yang lebih tinggi (misalnya, norma moral; nilai sosial; hak asasi } \\
\text { manusia). }\end{array}$ \\
\hline
\end{tabular}

Banyak para akademisi mengacu pada teori utilitas dan nilai sebagai potensi yang layak bagi stakeholder. Utilitas dipahami untuk mencerminkan nilai yang diterima stakeholder benar-benar memiliki manfaat bagi stakeholder sebagai fungsi utilitas - nilai stakeholder. Utilitas yang dirasakan stakeholder dari perusahaan, konsisten dengan persepsi pengaruh utilitas: (1) utilitas stakeholder yang terkait dengan barang dan jasa yang sebenarnya, (2) utilitas stakeholder yang terkait dengan keadilan, (3 ) afiliasi utilitas stakeholder, dan (4) utilitas stakeholder yang terkait dengan persepsi biaya peluang.

Perspektif stakeholder berbasis kinerja perusahaan didasarkan pada ide-ide inti dari semua stakeholder yang memiliki power untuk terlibat atau tidak dengan perusahaan dalam menentukan fungsi utilitas mereka sendiri. Jumlah utilitas yang mereka terima akan mempengaruhi apakah mereka memilih atau tidak terlibat dengan perusahaan dan bagaimana mereka bertindak ketika melakukan transaksi dengan perusahaan. 


\section{Nilai bagi Stakeholder}

Teori stakeholder sebagai teori penciptaan nilai menunjukkan bahwa nilai optimal untuk perusahaan dibuat ketika nilai agregat diciptakan untuk semua stakeholder, tanpa menggunakan instrumental apapun untuk meningkatkan penciptaan nilai bagi kelompok stakeholder. Dengan demikian, tujuannya adalah untuk bersama-sama menciptakan nilai bagi perusahaan dan stakeholder. Penciptaan, atau membuat nilai bagi para stakeholder mengacu pada nilai ekonomi, atau transaksi atau hubungan dengan perusahaan dalam enam jenis nilai berikut :

a. Nilai ekstrinsik ekonomi (nilai ekonomi), diciptakan melalui kolaborasi antara karyawan, perusahaan dan stakeholder.

b. Nilai ekstrinsik tidak berwujud, yang disediakan oleh perusahaan, misalnya, pengakuan, beberapa jenis pelatihan yang dilakukan oleh perusahaan. Nilai ekstrinsik tidak berwujud melengkapi nilai ekonomi (selain gaji, karyawan akan juga mengharapkan perusahaan untuk memberikan pengakuan).

c. nilai intrinsik psikologis, seperti kepuasan dengan pekerjaan yang dilakukan yang tidak dapat diambil oleh perusahaan atau stakeholder lainnya.

d. nilai transenden, yang terdiri dari pembelajaran evaluatif (akuisisi kebajikan atau keburukan) yang dihasilkan sebagai konsekuensi dari sebuah keputusan yang mempengaruhi kemampuan untuk membuat keputusan yang diperlukan untuk masa depan.

e. nilai eksternalitas positif atau negatif, yaitu, nilai yang dirasakan oleh hubungan atau transaksi yang dilakukan. Misalnya, hubungan antara karyawan dan perusahaan dapat menghasilkan pengetahuan yang dapat mempengaruhi proses pembelajaran evaluatif internalisasi efek nilai. Nilai intrinsik pembelajaran operasional seperti akuisisi pengetahuan dan kemampuan yang dapat berkontribusi pada penciptaan nilai ekonomi di masa depan

Arti penting teori stakeholder dalam pikiran manajer perusahaan adalah untuk menentukan apa yang sebenarnya mereka perhatikan, pertimbangkan dan kekhawatiran stakeholder dalam kebijakan perusahaan sehari-hari, siapa atau apa yang benarbenar penting. Tiga faktor penentu arti penting teori stakeholder yaitu power, legitimacy dan urgency. Power (kemampuan kelompok stakeholder untuk menghasilkan outcomes yang diinginkan), Legitimacy (sejauh mana hubungan kelompok stakeholder dengan perusahaan diterima secara sosial dan diharapkan), dan Urgency (tingkatan sensitifitas klaim kelompok stakeholder terhadap waktu). Kombinasi Power, Legitimacy dan Urgency menghasilkan tujuh jenis stakeholder, masing-masing memiliki arti penting bagi manajer dalam memperlakukan manajer itu sendiri (Reed, et al, 2009).

Arti penting klaim stakeholder akan tergantung pada struktur insentif yang dihadapi oleh manajer sebagai individu dan akan tidak terduga di tingkat perusahaan. Menempatkan kontnuitas budaya perusahaan - stakeholder dalam posisi moralitas bisnis tanpa kompromi dalam prinsip hubungan stakeholder, akan memainkan peran dalam ekonomi yang kompetitif. Diferensiasi tiga attribut, hirarki stakeholder memiliki pengaruh yang berbeda satu sama lain.

Prioritas stakeholder cenderung bervariasi, dalam beberapa konteks dimungkinkan untuk mengem-bangkan 
sistem untuk menilai legitimasi dan justifikasi kepentingan stakeholder, penggunaan kriteria sesuai dengan kebijakan perusahaan yang bersangkutan. Prioritas dapat dinilai pada tingkat dan derajat komitmen yang mendasari dan dampak yang dimiliki

Stakeholder memiliki derajat power yang berbeda dari untuk mengendalikan keputusan yang memiliki efek pada kebijakan perusahaan, dan memiliki derajat potensi kontribusi dan kepentingan yang berbeda dalam mencapai tujuan tertentu. Power untuk mempengaruhi kebijakan perusahaan berasal dari kontrol keputusan dengan efek positif atau negatif. dapat dipahami sebagai sejauh mana stakeholder mampu membujuk atau memaksa orang lain untuk membuat keputusan, dan mengikuti tindakan tertentu. Tekanan berasal dari sifat organisasi dan stakeholder (Higgins, 2010), atau posisi mereka dalam kaitannya dengan para stakeholder lainnya baik secara formal maupun informal.

Potensi untuk mempengaruhi, atau dipengaruhi oleh kebijakan perusahaan dengan karakteristik tertentu yang spesifik sesuai konteks dan lokasi. Perhatian khusus pada stakeholder yang memiliki potensi power yang sedikit lebih tinggi. Masalah, kebutuhan dan kepentingan stakeholder cenderung menjadi penting bagi banyak inisiatif untuk memperbaiki kebijakan dan proses bisnis. Informasi yang dihasilkan potensi power stakeholder dapat dikombinasikan dalam empat strategi umum seperti tabel 2. Jenis posisi stakeholder akan menunjukkan risiko relatif yang ditimbulkan oleh stakeholder tertentu, dan kemungkinan penyatuan dukungan untuk tindakan yang diusulkan atau perubahan kebijakan adalah pendekatan yang mengasumsikan bahwa pertimbangan etis tidak relevan atau tunduk kepada kebutuhan untuk memastikan bahwa beberapa stakeholder mendapatkan keuntungan atas orang lain.

Risiko dalam pendekatan semacam ini dilakukan dengan kategorisasi, representasi dan beberapa stakeholder mungkin kurang terwakili atau disalahpahami. Hal ini juga dapat mengabaikan posisi yang dimiliki oleh stakeholder yang berbeda - hubungannya dengan hak dan prinsip-prinsip keadilan dan keberlanjutan - yang tidak dapat dengan mudah ditangani dengan pendekatan sederhana. Namun demikian isu-isu pendekatan ini seringkali penting untuk perubahan prospek dan proses bisnis.

Dalam praktik bisnis, saat strategi dimonitor oleh stakeholder, itu berarti stakeholder memberi peluang kepada perusahaan untuk memahami perspektif stakeholder lebih akurat, dan menjadi langkah awal untuk mengelola aspirasi stakeholder yang lebih efektif.

\section{KINERJA BISNIS}

Para akademisi ekonomi memberikan wawasan berguna setidaknya dalam dua perspektif "nilai". Pertama, premis utama dari kekayaan perusahaan adalah bahwa individu tahu apa nilai yang terbaik bagi mereka, individu harus menentukan diri mereka sendiri dan tidak memungkinkan orang lain untuk memilih menggantikan mereka. Kedua, pasar yang sehat memungkinkan pelanggan untuk memilihapa yang akan mereka beli, dari siapa, dan di bawah persyaratan apa. Pasar seperti itu juga beroperasi untuk peran stakeholder lainnya, termasuk untuk pekerjaan (misalnya, untuk siapa saya bekerja, dengan persyaratan apa, untuk kompensasi apa). Dasar-dasar dari pasar bahwa orang akan cenderung untuk membuat pilihan yang memberikan mereka nilai yang paling optimal dan lebih menarik dan mendorong pergeseran pilihan pelanggan (Laplume \& Litz, 2008). 
Table 2. Hubungan Strategis Stakeholder dan Manajemen

\begin{tabular}{|l|l|l|}
\hline Potential & \multicolumn{1}{|c|}{ High } & \multicolumn{1}{|c|}{ Low } \\
Power & High & $\begin{array}{l}\text { Collaborate } \\
\text { impacts, defend } \\
\text { against }\end{array}$ \\
\hline Low & $\begin{array}{l}\text { Involve, build } \\
\text { capacity and secure } \\
\text { interests }\end{array}$ & $\begin{array}{l}\text { Monitor or } \\
\text { ignore }\end{array}$ \\
\hline
\end{tabular}

Para akademisi membangun konsep perbedaan utilitas nilai kualitatif. Utilitas dimaknai sebagai “kebahagiaan, kesejahteraan" yang digunakan untuk mengukur bagaimana persepsi stakeholder tentang nilai yang mereka terima melalui interaksi mereka dengan perusahaan.

\section{Maksimalisasi Nilai Perusahaan}

Definisi nilai dalam bidang ekonomi dan keuangan menunjuk pada kesejahteraan ketika semua perusahaan dalam kondisi perekonomian yang mampu memaksimalkan nilai perusahaan. Intuisi di balik kriteria ini adalah ketika perusahaan menghasilkan output atau serangkaian output dihargai oleh pelanggan lebih dari nilai input (termasuk pemasok) dalam produksi. Nilai perusahaan adalah nilai pasar jangka panjang (Jensen, 2002).

Kriteria memaksimalkan nilaimemaksimalkan kesejahteraan tidak berlaku dalam kondisi pasar monopoli. Memaksimalkan total nilai pasar perusahaan merupakan jumlah ekuitas nilai pasar dibanding nilai hutang. Fungsi tujuan bisa memandu manajer perusahaan dalam membuat keputusan, maksimalisasi nilai adalah salah satu yang penting karena menyebabkan beberapa kondisi untuk maksimalisasi kesejahteraan.

a. Menciptakan nilai bagi stakeholder

Pencapaian nilai stakeholder serta pencapaian kinerja keuangan berakar pada cara perusahaan melakukan bisnis sebagai strategi tingkat korporasi. Komitmen penciptaan nilai cenderung gagal jika mengabaikan isu nilai-nilai inti perusahaan. Strategi tingkat perusahaan fokus pada (a) tujuan dan nilai-nilai; (b) stakeholder dan prinsipprinsip; (c) konteks sosial dan tanggung jawab; dan (d) kepemimpinan etis. Transparansi nilai stakeholder dan strategi penciptaan nilai akan membuat lebih mudah untuk menarik karyawan (dan stakeholder lainnya) yang mendukung strategi penciptaan nilai, memungkinkan komitmen stakeholder lebih besar.

\section{b. Menciptakan Nilai Ekonomi}

Dalam teori neoklasik, nilai ekonomi akan muncul ketika harga barang dan jasa yang dibayar konsumen lebih besar dari biaya produksi. Biaya produksi barang dan jasa adalah biaya kesempatan sumber daya yaitu, keuntungan yang bisa diperoleh dari penggunaan alternatif sumber daya terbaik. Selain itu, nilai ekonomi yang dihasilkan adalah jumlah surplus konsumen dan surplus produsen. Surplus konsumen didefinisikan sebagai perbedaan antara harga tertinggi yang untuk satu produk atau pelayanan yang baik dan harga yang benar-benar dibayar oleh konsumen, sementara surplus produsen adalah selisih antara harga jual dan biaya sumber daya yang digunakan. Maksimalisasi nilai sebenarnya berakar pada surplus konsumen dan surplus produsen atau nilai sisa yang dikaitkan dengan biaya awal proses bisnis untuk menghasilkan produk (Argandona, 2011).

Jika sebuah produk mampu memenuhi kebutuhan konsumen saat 
ini lebih baik tanpa kehilangan kemampuannya untuk memenuhi kebutuhan masa depan (sustainable), maka inilah nilai lebih yang dibuat oleh pembeli karena mereka bersedia membayar produk pada harga yang lebih tinggi, dan jika produser menggunakan teknologi yang lebih baik, menggabungkan sumber daya yang lebih efisien atau membayar harga proses produksi lebih rendah, akan menghasilkan nilai ekonomi yang lebih maksimal.

Masalah penciptaan nilai terpisah dari distribusi nilai. Jika kondisi terpenuhi, konsumen menerima surplus mereka, penyedia sumber daya menerima biaya kesempatan mereka, dan pemilik perusahaan yang sesuai dengan surplus produsen atau keuntungan, yang merupakan insentif bagi mereka untuk membuat keputusan yang memaksimalkan keuntungan dan efisiensi masa depan.

Nilai ekonomi perusahaan yang optimal atau maksimalisasi nilai bagi perekonomian secara keseluruhan dapat dicapai. Jika konsumen dapat memaksimalkan utilitas mereka dan perusahaan memaksimalkan keuntungan bagi pemilik (yaitu, nilai sekarang yang diharapkan dari saham, dengan asumsi jangka panjang), nilai ekonomi yang diciptakan akan maksimal.

Surplus konsumen juga akan meningkat jika perusahaan mengurangi harga jual. Hal ini bisa terjadi, misalnya, jika ada persaingan di pasar barang, yang mempengaruhi baik surplus konsumen maupun surplus produsen. Perusahaan yang terlibat dalam praktik yang bertujuan menutup pesaing untuk mening-katkan surplus konsumen dalam jangka panjang.
Kurangnya kompetisi membuka pintu untuk strategi lain - diskriminasi harga, penciptaan captive market, dan sebagainya dimana perusahaan berusaha untuk menghasilkan surplus konsumen. Dalam model stakeholder, teori penciptaan nilai menyiratkan bahwa:

- semua orang yang menciptakan nilai, atau dalam hubungan mereka dengan perusahaan akan menghadapi risiko, baik dalam perusahaan (pemilik, manajer, karyawan) atau di luar perusahaan (konsumen, pemasok), atau dampak eksternalitas korporasi atau informasi yang salah (masyarakat setempat, lingkungan, generasi mendatang, masyarakat luas), harus dipertimbangkan oleh stakeholdersetidaknya untuk tujuan distribusi nilai;

- memaksimalkan nilai bagi konsumen dan penyedia sumber daya tidak cukup untuk menjamin nilai kesejahtraan dalam konteks sosial, karena ada pihak lain yang masih harus dipertimbangkan, dan

- dalam hubungan antara stakeholder dan perusahaan, selain harga pertukaran barang atau jasa, variabel lain yang harus diperhitungkan adalah apakah ada alternatif yang membatasi power pasar, apakah informasi yang diberikan (termasuk sarana memprosesnya dan menggunakannya rasional), apakah perlindungan yang tersedia terhadap eksternalitas negative, apakah mereka yang terkena dampak memiliki sarana untuk membela diri, dan sebagainya. Dengan demikian memaksimalkan nilai ekonomi 
bagi seluruh stakeholder tidak menjamin nilai maksimum untuk setiap stakeholder; bahkan tidak menjamin distribusi nilai yang efisien dan adil.

Faktor-faktor yang menjelaskan nilai proses produksi adalah: (a) sebagai hasil negosiasi atau konfrontasi antara stakeholder dan perusahaan, dan dalam beberapa kasus antara beberapa stakeholder dan lain-lain, masingmasing dengan power relatif mereka; (b) sebagai hasil dari strategi perusahaan untuk mencapai hasil ekonomi atau non-ekonomi dalam jangka panjang, dan (c) sebagai hasil dari tindakan yang berangkat dari logika power dan pendekatan logika atau gratifikasi.

Hasil kolaborasi antara perusahaan dan stakeholder, tergantung pada power relatif dari masing-masing pihak. Ekonomi menyediakan petunjuk tentang sifat power. Power karya-wan, misalnya, akan tergantung pada karakte-ristik barang atau jasa pasar bersangkutan, yaitu:

- Elastisitas harga permintaan: di mana permintaan untuk suatu produk adalah kaku, karyawan akan mampu bekerja pada sebagian besar pekerjaan yang menghasilkan surplus konsumen. Elasti-sitas permintaan tergantung pada apakah ada barang pengganti yang tersedia; apakah barang tersebut barang mewah atau kebutuhan primer; apakah harga barang merupakan sebagian besar atau kecil dari pendapatan konsumen, dan seberapa mudah mengaksesnya,
- Power pasar perusahaan: karyawan perusahaan monopoli cenderung memiliki penghasilan yang relatif lebih tinggi.

- Ruang lingkup stakeholder yang bertujuan apropriasi dari para stakeholder lainnya, atau perusahaan (misalnya, bagaimana manajer dapat bergabung dengan karyawan untuk meraih keuntungan).

- Elastisitas permintaan sumber daya akan tergantung pada elastisitas permintaan barang, keberadaan dan kedekatan sumber daya pengganti, dan pengeluaran sumber daya sebagai persentase dari harga yang baik .

- Tingkat persaingan di pasar sumber daya, yaitu tingkat monopoli bilateral antara sisi permintaan dan sisi penawaran,

- Biaya penggantian beberapa sumber daya dengan orang lain, atau dari meninggalkan transaksi.

\section{c. Justifikasi Nilai Ekonomi Stakeholder}

Maksimalisasi keuntungan menunjuk pada semua produksi dan aliran uang tunai berjalan tak terbatas pada saat ini dan masa depan. Efek kesejahteraan lahir dari keputusan perusahaan dalam menggunakan sumber daya perekonomian dalam bentuk tenaga kerja, modal, atau bahan yang dibeli dari harga pasar. Perusahaan menggunakan input ini untuk menghasilkan output barang atau jasa yang kemudian dijual ke konsumen melalui transaksi di pasar.

Dalam situasi yang sederhana perusahaan menempatkan output barang dan jasa untuk meningkatkan kesejahteraan agregat jika harga 
penjualan barang lebih dari biaya pembelian input. Perusahaan harus memperluas output selama tambahan nilai ekonomi dihargai oleh konsumen dari produk tambahan. Perbedaan antara pendapatan dan biaya-biaya adalah keuntungan maksimal yang mengarah pada hasil yang efisien.

Dalam teori manajemen strategis dimana kinerja ekonomi merupakan konsep penting dalam pengembalian aset atau return on asset (ROA). Demikian juga pendekatan berbasis sumber daya konsep ini sangat populer, dengan penekanan pada pengembangan keunggulan kompetitif untuk meningkatkan penciptaan nilai ekonomi. Teori stakeholder memer-lukan pembenaran dalam ekonomi untuk menjelaskan bahwa manajemen dan stakeholder berkaitan dengan kinerja keuangan yang lebih tinggi.,

- hubungan stakeholder- manajemen saling menguntungkan dapat meningkatkan kapasitas kekayaan perusahaan, sedangkan kegagalan hubungan itu kapasitas kekayaan di masa depan akan terganggu.

- Menghindari hasil negatif / pengurangan risiko menciptakan lebih banyak (ROA) dan lebih stabil.

- Peningkatan kemampuan beradaptasi dan fleksibilitas manajemen yang lebih efektif dalam kontrak perusahaan multilateral yang lebih besar

- Perpanjangan teori keagenan pemegang saham pada stakeholder akan memotivasi manajer bersama-sama dengan stakeholder secara efisien untuk mencapai tujuan keuangan, reputasi pasar yang sangat baik merupakan potensi bagi kemitraan bisnis, karyawan dan pelanggan

- Memfasilitasi pembentukan aliansi, kontrak jangka panjang dan perusahaan patungan.

- Sumber keunggulan kompetitif perusahaan menciptakan sejumlah pilihan peluang bisnis yang lebih baik.

- Peningkatan kepercayaan pemasok dan masyarakat menyebabkan biaya transaksi yang lebih sedikit dengan mengurangi sumber daya yang dibutuhkan untuk membuat kontrak dengan menghilangkan kebutuhan pemantauan dan pengamanan.

- Stakeholder lebih cenderung mengungkapkan informasi berharga yang dapat menyebabkan inovasi dan efisiensi yang lebih besar.

Ragam penelitian dalam bidang manajemen cukup mengesankan dalam mendukung gagasan nilai ekonomi stakeholder merupakan layanan atas kepentingan berbagai stakeholder dan layanan tersebut terkait dengan kinerja keuangan yang lebih tinggi, reputasi, dan kinerja perusahaan. Pembenaran ekonomi terkuat menemukan hubungan stakeholder tidak hanya memungkinkan perusahaan untuk menikmati superior kinerja keuangan dalam jangka waktu yang lama, tetapi juga membantu memperbaiki buruknya kenerja perusahaan lebih cepat.

\section{Kenerja Keuangan}

Sejauh ini beberapa konsep ekonomi fundamental dan literatur stakeholder berkaitan dengan konstruksi value. Dalam perspektif stakeholder berbasis kinerja didefinisikan sebagai total nilai yang dicip- 
takan oleh perusahaan melalui kegiatannya untuk masing-masing stakeholder perusahaan.

Kinerja perusahaan dalam banyak literatur bisnis dan ekonomi difokuskan pada penyediaan pengembalian atas investasi (ROI), imbal hasil bagi pemegang saham. Banyak akademisi percaya bahwa pemegang saham harus menjadi prioritas dari stakeholder perusahaan, karena pemegang saham tidak memiliki kontrak spesifik dengan perusahaan, mereka hanya terikat dengan perjanjian keuntungan dan investasi mereka. Logikanya memberikan pengembalian maksimal kepada pemegang saham adalah tugas utama dari manajer perusahaan.

\section{a. Nilai kinerja keuangan}

Dari perspektif stakeholder, metrik kinerja keuangan penting untuk semua stakeholder inti yang terlibat dalam keberhasilan perusahaan. Kinerja keuangan menawarkan perspektif penting pada penciptaan nilai, terutama ketika mereka terikat dengan upaya untuk mengukur kinerja keuangan yang spesifik dan terukur dalam jangka pendek atau jangka menengah dan dengan demikian mengurangi kemampuan dan atau keinginan manajer untuk berpikir tentang apa yang dillakukan oleh perusahaan untuk meningkatkan total nilai seluruh stakeholder (Berman et al, 1999)

Mengukur kinerja melalui faktor tangible dan intangible penting bagi stakeholder inti, memungkinkan korporasi untuk lebih memahami apa yang diinginkan oleh stakeholder dan dibutuhkan sebagai ukuran retrospektif tentang seberapa baik perusahaan telah dilakukan dan untuk membantu ide-ide baru tentang bagaimana perusahaan tampil di masa depan. Jika kemampuan untuk membuat utilitas stakeholder, dan menjadi prediktor utama dari kinerja perusahaan di masa depan, maka penting untuk menemukan gagasan yang lebih kompleks dari nilai secara sistematis. Jika perusahaan menggunakan metrik kinerja dalam melacak utilitas yang dibuat oleh stakeholder akan sangat bermanfaat dalam menentukan potensi sumber masalah yang mengurangi jumlah total nilai yang diciptakan.

Kinerja keuangan adalah penting bagi banyak stakeholder perusahaan. Ide dasarnya adalah bahwa perusahaan harus melayani berbagai stakeholder berdasarkan partisipasi mereka dalam skema kerja sama stakeholdermanajemen untuk menciptakan nilai, dan mempertahankan kelangsungan hidup perusahaan, termasuk pelanggan, masyarakat di mana perusahaan beroperasi, pemasok capital, peralatan, bahan, dan tenaga kerja.

\section{b. Distribusi output keuangan}

Konsep ini menggambarkan teori stakeholder siapa yang menerima nilai perusahaan, dan mungkin menimbulkan konflik antar pemegang saham dan stakeholder lainnya dalam hal siapa mendapat apa. Jika teori stakeholder dan teori pemegang saham menyediakan skema yang berbeda untuk mendistribusikan kekayaan (surplus, keuntungan), maka kontras antar mereka semakin tajam. Klaim distribusi sebagai bagian penting dari teori stakeholder terutama tentang proses dan keadilan prosedural dalam mengalokasikan surplus - kekayaan perusahaan kepada para stakeholder, keterlibatan stakeholder dalam kegiatan perusahaan mempengaruhi bagaimana mereka melihat distribusi sumber daya, dan keterlibatan mereka juga dapat 
menciptakan peluang baru dalam sebuah perusahaan yang dievaluasi memperbesar penciptaan nilai. berdasarkan estimasi pertumbuhan Stakeholder akan menerima hasil pendapatan perusahaan dan capaiannya ketika mereka melihat distribusi dibandingkan dengan tahun sebelumnya, keuangan dalam proses yang adil, jumlah lini usaha, wilayah pemasaran, termasuk informasi adalah sesuatu jumlah stakeholder yang terlibat dalam yang berharga dapat dibagi di antara perusahaan dan variabel lain yang mungkin para stakeholder.

\section{KESIMPULAN DAN REKOMENDASI}

Perlakuan terhadap stakeholder merupakan masalah penting dalam analisis hubungan kerja kontemporer. Model perusahaan memperlakukan power kelompok stakeholder akan mempengaruhi kinerja perusahaan Dengan meningkatnya voice stakeholder, nilai perusahaan, dan advokasi terhadap peran stakeholder dapat menopang mekanisme kebijakan manajerial. Konsep stakeholder menjadi salah satu kerangka acuan yang banyak digunakan dalam bisnis terutama stakeholder yang memiliki pengaruh signifikan terhadap arah, kebijakan dan kinerja bisnis secara keseluruhan.

Teori stakeholder ini dapat direkomendasikan untuk menditeksi potensi kepentingan stakeholder terutama yang terkait dengan kebijakan perusahaan, oleh karena itu sejumlah masalah yang dapat dikaji secara empiris dalam penelitian misalnya berkaitan dengan (1) siapa yang tergantung pada siapa?, (2) ukuran kinerja stakeholder? (3) bagaimana organisasi bisa dipengaruhi atau dibangun ? (4) siapa yang memiliki kontrol atas sumber daya ? (5) siapa yang memiliki kontrol atas informasi ? (6) dimana para stakeholder mempengaruhi prioritas untuk mengatasi atau mengurangi penggunaan sumberdaya perusahaan?, (7) kebutuhan, kepentingan dan harapan stakeholder mana yang diprioritaskan sehubungan dengan kebijakan perusahaan?. Demikian juga dimensi power, ligitimasi dan urgensi dapat dikaitkan dengan kinerja bisnis tanamkan dalam perusahaan.

\section{DAFTAR PUSTAKA}

Abell, P. 2009. A the for thes: Comparative Narratives in Sociological Explanation. Sociological Methods \& Research, Vol 38 No 1, pp 38-70.

Ackermann, Fran and Eden, Colin. 2011. Strategic Management of Stakeholders:Theory and Practice. Long Range Planning, 44, pp 179-196

Argandona A. 2011. Stakeholder Theory and Value Creation. IESE Business School.: Vol 92 No 2, pp 1-13

Berman, Shawn L; Wicks, Andrew C; Kotha, Suresh; and Jones, Thomas M. 1999. Does stakeholder orientation matter? The relationship between Stakeholder Management Models and corporate Financial Performace. Academy of Management Journal; Vol 42, No 5, pp 488 - 506.

Brand, R., \& Gaffikin, F. 2007. Collaborative Planning in an Uncollaborative World. Planning Theory, Vol 6 No 3, 282-313.

Diez, Jose, Luis, Godos. Gago, Roberto Fernández and García, Laura, Cabeza. 2015. Normative Stakeholder Management Orientation: Business Vs. Non-Business Students. Society and Economy. Vol 37 No 4, pp. 477-492.

Donaldson, Thomas and Lee E. Preston. 1995. The Stakeholder Theory of the Corpo-ration: Concepts, Evidence, and Impli-cations. The Academy of 
Management Review, Vol. 20, No. 1, pp. 65-91

Harrison, Jeffrey S. and Wicks, Andrew C. 2013. Stakeholder Theory, Value, and Firm Performance. Business Ethics Quarterly. Vol 23, No 1, pp. 97-124

Higgins, E. R. E. 2010. Corporations, Civil Society, and Stakeholders: Journal of Business Ethics, Vol 94 No 2, pp 157-176.

Jensen. Michael C. 2002. Value Maximization, Stakeholder Theory, and the corporate Objective Function. Business Ethics Quarterly, Vol 12,No 2, pp. 235-256

Jones, Thomas M., Will Felps and Gregory A. Bigley. 2007. Ethical Theory And Stakeholder Related Decisions: The Role of Stakeholder Culture. The Academy of Management Review. Vol. 32, No. 1, pp 137-155.

Klijn, E.-H., Steijn, B., \& Edelenbos, J. 2010. The Impact of Network Management on Outcomes in Governance Networks. Public Administration, Vol 88 No 4, pp 1063-1082.

Laplume, A. O., Sonpar, K., \& Litz, R. A. 2008. Stakeholder Theory: Reviewing a Theory That Moves Us. Journal of Management, Vol 34 No 6, pp 11521189.

Mitchell, Ronald K., Bradley R. Agle, Donna J. Wood. 1997. Toward a Theory of Stakeholder Identification and Salience: Defining the Principle of who and what really counts. The Academy of Management Review, Vol. 22, No. 4, pp. 853-886

Parmar, Bidhan L., R. Edward Freeman. Jeffrey S. Harrison, Andrew C. Wicks., Simone de Colle and Lauren Purnell. 2010. Stakeholder Theory:
The State of The Art. The Academy of Management Annals. pp 1-61.

Reed, M. S., Graves, A., Dandy, N., Posthumus, H., Hubacek, K., Morris, J. 2009. Who's in and Why? A Typology of Stakeholder Analysis Methods for Natural Resource Management. Journal of Environmental Mana-gement, Vol 90 No 5, pp 1933-1949.

Takis K. and Yannis K. 2007. Strategic management, corporate responsibility and stakeholder management Integrating corporate responsibility principles and stakeholder strategy: a stakeholder-oriented and integrative strategic management framework. corporate Governance. Vol. 7 No. 4, pp. 355-369,

Torfing, J. 2005. Governance Network Theory: Towards a Second Generation. European Political Science. Vol 4 No 3, pp 305-315. 